\title{
Detection of Virulence Factors of Local Isolates of Proteus mirabilis
}

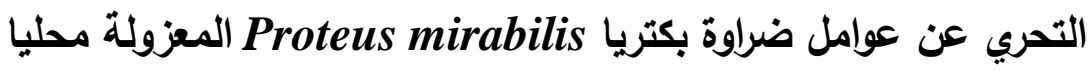

\author{
Touka H. Ali and Hameed M. Jasim* \\ *Departments of Biotechnology, College of Science, Al-Nahrain University, Baghdad-Iraq. \\ E-mail: touka_1r@yahoo.com.
}

\begin{abstract}
A total of eighty five samples were collected from different clinical and food samples includes twenty samples of urine, forty five samples from wounds, and twenty samples of chicken and meat. From the overall samples a total of $1 \leq 7$ isolates were obtained, and among the monly fifteen isolates were belong to $P$. mirabilis according to the results of identification by studying their morphological and cultural characteristics and biochemical tests. Results of identification were confirmed by using Apir.E system. Pathogenicity of local isolates of $P$. mirabilis was examined by detecting several virulence factors includes invasion and adhesion ability and protease production. Results showed that the adhesion of these isolates to uroepithelial was ranged between r.-.00 bacterial cell/uroepithelial cell, and number of bacterial cells invade uroepithelial cells was ranged between $1-r$. bacterial cell/uroepithelial cell. Furthermore all of the isolates of P.mirabilis were able to produce protease as another virulence factor forpathogenicity. the diameter of zone of hydrolysis on skim milk agar was ranged between $0_{-1} \leq \mathrm{mm}$ for different isolates. Specific activity of protease produced in culture filtrates of these isolates was ranged between $1 \leqslant, 0$ and $,, 1,1 \mathrm{U} / \mathrm{mg}$ protein. The most virulent isolate was $P$. mirabilis $\mathrm{P} \backslash 0$ isolated from urine of urinary tract infection because of its high ability to produce these virulence factors.
\end{abstract}

Keywords: Proteus mirabilis, virulence, adhesion, invasion, protease.

\section{Introduction}

Proteus species, members of the family Enterobacteriaceae are motile Gram negative enteric bacteria. They are important pathogens of the urinary tract and are the primary infectious agent in patients with indwelling urinary catheters. Individuals suffering from urinary tract infections caused by Proteus mirabilis often develop bacteriuria, cystitis, kidney and bladder stones, catheter obstruction due to stone encrustation, acute pyelonephritis, and fever (1). Several potential virulence factors of Proteus had been studied in relation to its virulence and pathogenicity, including hydrolysis of urea by urease, cell invasiveness, cytotoxicity induced by hemolysins, and adherence to the uroepithelium mediated by fimbriae. There were many proposed mechanisms and influencing factors for the invasive properties of P.mirabilis. Microbial invasion could be facilitated by virulence factors, microbial adherence, and resistance to antimicrobials. Virulence factors assisted pathogens in invasion and resistance of host defenses. Bacterial proteins with enzymatic activity (e.g. protease, elastase, and collagenase) facilitated local tissue spread. Microbial adherence to surfaces helps microorganisms establish a base to penetrate tissues. The adhesive properties in the Enterobacteriaceae were generally mediated by different types of pili $(r)$.

Haemolysin, which is cytotoxic for cultured urinary tract epithelial cells, had been shown to be correlated with the ability of bacteria to invade cells. The abilityof P.mirabilis to express virulence factors, including urease and haemolysin, and to invade humanurothelial cells, is coordinately regulated with swarming differentiation ( $r$ ). According to these findings, this study was aimed to isolate P.mirabilis from different clinical and food samples and studying there virulence factors affects their pathogenicity. 


\section{Methods}

\section{Collection of Samples}

Clinical samples (urine specimens and swabs samples from wounds) were collected from patients in Al-Yarmok hospital and food samples (chicken and meat samples) collected from local markets in Baghdad city.

\section{Isolation of $\boldsymbol{P}$. mirabilis}

For the isolation of $P$. mirabilis from urine samples, loop full of undiluted urine was taken and spread on blood agar and MaConkey agar plates, while swabs taken from wounds were streaked on blood agar medium and McConkey agar medium, then plates were incubated at ${ }^{\mathrm{V}}{ }^{\circ} \mathrm{C}$ for $1 \wedge \mathrm{hrs}$. On the other hand, ' $\mathrm{g}$ of each meat sample was transferred to containers of $99 \mathrm{ml}$ of nutrient broth and incubated at $\mathrm{rv}^{\circ} \mathrm{C}$ for overnight under aerobic conditions. Then $1 \mathrm{ml}$ of broth of each sample was transferred to test tubes containing $1 \cdot \mathrm{ml}$ of Tetrathionate broth and $1 \mathrm{ml}$ of the same sample to 1. $\mathrm{ml}$ of Rappaport-Vassiliadis RV broth and incubated at ${ }^{\circ}{ }^{\circ} \mathrm{C}$ for overnight. After incubation aloop full of sample was taken and spread on Xylose Lysine deoxycholate XLD agar, blood agar and MaConkey agar plates and incubated at $\mathrm{rv}^{\circ} \mathrm{C}$ for overnight under aerobic conditions. After incubation, suspected colonies were selected and subjected to identification according to their morphological and cultural characteristics and biochemical tests $(\varepsilon)$.

\section{Identification of $\boldsymbol{P}$. mirabilis}

Morphological and cultural characteristics (size, shape, edge, color, and margin) of the bacterial coloniesand biochemical tests were examined as described by Atlaset al. ( $\left.{ }^{\circ}\right)$. P. mirabilis isolates were further identified according tobiochemical reaction by using Api $r \cdot$ E system ( (\urcorner$)$.

\section{Detection of Virulence Factors Adherence and Invasion assay}

Adherence and Invasion assayof local isolates of $P$. mirabilis was achieved according to Iwahiet al. $(\mathrm{V})$

\section{Production of Protease}

Semi Quantitative Screening for detection of protease production by local isolates of
$P$. mirabilis was achieved according to Sneathet al. (^) by measuring the diameter of hydrolysis zones around colony of each bacterial isolate. While quantitative screening was achieved according to Manachiniet al. (9) by measuring the release of trichloroacetic acid TCA soluble peptides from $1 \%(\mathrm{w} / \mathrm{v})$ casein solution. Enzyme activity and specific activity was calculated as follows:

Enzyme activity $(\mathrm{U} / \mathrm{ml})=$ absorbance at $r \wedge \cdot n m$

$\overline{\mathrm{k}(\cdot \cdot 1) \times \operatorname{time}(r \cdot \min .) \times \operatorname{enzyme} \text { vol. }(\cdot . r \mathrm{ml})}$

Specific activity $(\mathrm{U} / \mathrm{mg})=$ activity $(\mathrm{U} / \mathrm{ml})$

$\overline{\text { protein concentration ( } \mathrm{mg} / \mathrm{ml} \text { ) }}$

\section{Protein concentration}

Protein concentration in culture filtrates was determined according to the method described by Bradford, ( $\cdot$ •)

\section{Results and Discussion \\ Isolation of $\boldsymbol{P}$. mirabilis}

In order to isolate $P$. mirabilis, different samples (clinical and food samples) were collected from different locations in Baghdad city during the period from $11-r \cdot 1 r$ to $r_{-}$ $Y \cdot 1 r$. Results indicated in Table (1) show that To of clinical samples (includes urine samples from patients with urinary tract infection and swabs from wounds) and $r \cdot$ of food samples (chicken and meet) were obtained. 
Table (')

Bacterial isolates obtained from different sources.

\begin{tabular}{|c|c|c|c|}
\hline Source of sample & No. of samples & No. of isolates & $\begin{array}{c}\text { No. of Proteus spp. } \\
\text { isolates }\end{array}$ \\
\hline Urine & $r \cdot$ & 0 & 1 \\
\hline wounds & $\sum 0$ & 90 & IY \\
\hline Chicken and meat & $r \cdot$ & \&7 & 14 \\
\hline Total & 10 & $1 \leq 9$ & Y4 \\
\hline
\end{tabular}

From all of these samples, a total of $1 \leq 7$ different isolates were obtained, these isolates were cultured on blood and MacConky agar medium as a differential medium to differentiate Proteusspp. from clinical samples, and on blood, MacConky agar and XLD agar medium for chicken and meat samples. Among the total isolates, $Y r$ of them were suspected to be belonging to Proteus spp. according to their morphological and cultural characteristics as they were able to grow on MacConky agar medium for $r \leqslant$ hrs. at ${ }^{\mathrm{N}}{ }^{\circ} \mathrm{C}$, and appeared as pale colonies with swarming motility on blood agar medium. Under light compound microscope they were appeared Gram negative, rods, and non-spore formers.

Table (')

Biochemical tests for identification of Proteus mirabilis isolates.

\begin{tabular}{|c|c|c|c|c|c|c|c|c|c|c|c|c|c|c|c|c|}
\hline \multicolumn{2}{|c|}{ Symbol Test } & $P^{\prime}$ & $P^{r}$ & $P^{\mu}$ & $P \varepsilon$ & $P^{0}$ & $P^{\tau}$ & $P^{V}$ & $P^{\wedge}$ & $P^{q}$ & $P 1$. & $P 11$ & $P, P$ & $P \mid r$ & $P \mid \varepsilon$ & $P 16$ \\
\hline \multicolumn{2}{|c|}{ Oxidase } & - & - & - & - & - & - & - & - & - & - & - & - & - & - & - \\
\hline \multicolumn{2}{|c|}{ Catalase } & + & + & + & + & + & + & + & + & + & $\begin{array}{llll}+ & & & \end{array}$ & + & + & + & + & + \\
\hline \multicolumn{2}{|c|}{ Motility } & + & + & + & + & + & + & + & + & + & + & + & + & + & + & + \\
\hline \multicolumn{2}{|c|}{$\begin{array}{l}\text { Phenylalanine } \\
\text { - deaminase }\end{array}$} & + & + & + & + & + & + & + & + & + & + & + & + & + & + & + \\
\hline \multicolumn{2}{|c|}{ Indole } & - & - & - & - & - & - & - & - & - & - & - & - & - & - & - \\
\hline \multicolumn{2}{|c|}{ Urease } & + & + & + & + & + & + & + & + & + & + & + & + & + & + & + \\
\hline \multicolumn{2}{|c|}{ Simon citrate } & - & - & - & - & - & - & - & - & - & - & - & - & - & - & - \\
\hline \multirow{3}{*}{$\begin{array}{l}\text { Kligle } \\
\mathbf{r} \\
\text { iron } \\
\text { agar }\end{array}$} & $\begin{array}{l}\text { Slat/ } \\
\text { Butt }\end{array}$ & $\begin{array}{l}\text { K/ } \\
\mathbf{A}\end{array}$ & $\begin{array}{l}\mathbf{K} / \\
\mathbf{A}\end{array}$ & $\begin{array}{l}\text { K/ } \\
\mathbf{A}\end{array}$ & $\begin{array}{l}\text { K/ } \\
\text { A }\end{array}$ & $\begin{array}{l}\mathbf{K} / \\
\mathbf{A}\end{array}$ & $\begin{array}{l}\text { K/ } \\
\mathbf{A}\end{array}$ & $\begin{array}{l}\text { K/ } \\
\text { A }\end{array}$ & $\begin{array}{l}\text { K/ } \\
\mathbf{A}\end{array}$ & $\begin{array}{l}\text { K/ } \\
\mathbf{A}\end{array}$ & $\begin{array}{l}\mathbf{K} / \\
\mathbf{A}\end{array}$ & $\begin{array}{l}\mathbf{K} / \\
\mathbf{A}\end{array}$ & $\begin{array}{l}\mathbf{K} / \\
\mathbf{A}\end{array}$ & $\begin{array}{l}\text { K/ } \\
\text { A }\end{array}$ & $\begin{array}{l}\text { K/ } \\
\text { A }\end{array}$ & $\begin{array}{l}\text { K/ } \\
\text { A }\end{array}$ \\
\hline & HrS & + & + & + & + & + & + & + & + & + & + & + & + & + & + & + \\
\hline & COr & + & + & + & + & + & + & + & + & + & + & + & + & + & + & + \\
\hline
\end{tabular}

(-): Negative results, (+): positive results, $K / A$ : alkaline/acid

These 10 isolates were subjected to identification by using Api $r \cdot E$ system.

\section{Identification of $\boldsymbol{P}$. mirabilis}

Several biochemical tests were achieved to identify the isolates of Proteus spp. Results mentioned in Table ( $r$ ) show that 10 of these isolates were positive for catalase, urease, phenylalanine - deaminase, motile and Kliglerironagar, and gave negative results for utilizing Simoncitrate, oxidase and indole tests. These results were agreed with those obtained by Stankawskaet al. (1). 
Detection of the virulence Factors Produced by $\boldsymbol{P}$. mirabilis Isolates

Virulence factors produced by local isolates of $P$. mirabilis were investigated. These virulence factors include adhesion and invasion and protease production in different growth media.

\section{Adherence and Invasion}

Ability of Proteus mirabilis local isolates to adhere to uroepithelial cells is considered as an important virulence factor in pathogenesis of urinary tract infections ( $I$ ). In this study, the adherence of bacterial cells of $P$. mirabilis isolates to uroepithelial cells was detected

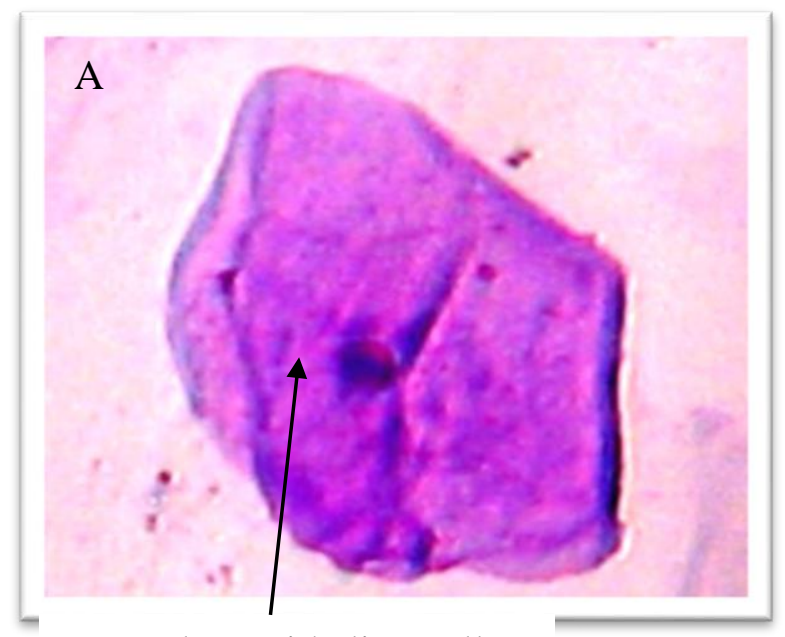

Normaluroepitheliumcell under oil-immersion lens of light compound microscope as shown in Fig.(1). This figure showed bacterial cells infectsuroepithelial cell that appears as rods. On the other hand, results indicated in Table ( $\left.{ }^{r}\right)$ show that the highest number of adhering bacteria to UEP was ranged from $r \cdot .00$ bacterial cell / uroepithelial cell. These results were in agreement with Perez-Serrano et al.(1 1 ) who found that the adherence of P.mirabilis to UEPCs ranged between $r \cdot .00$ bacterial cell/ uroepithelial cell. In other study on the adhesion of $P$. mirabilis to uroepithelial cell Al-kabby, ( $(\varepsilon)$ found that the adhesion range of $P$. mirabilis to uroepithelial cells was $r, 1$.

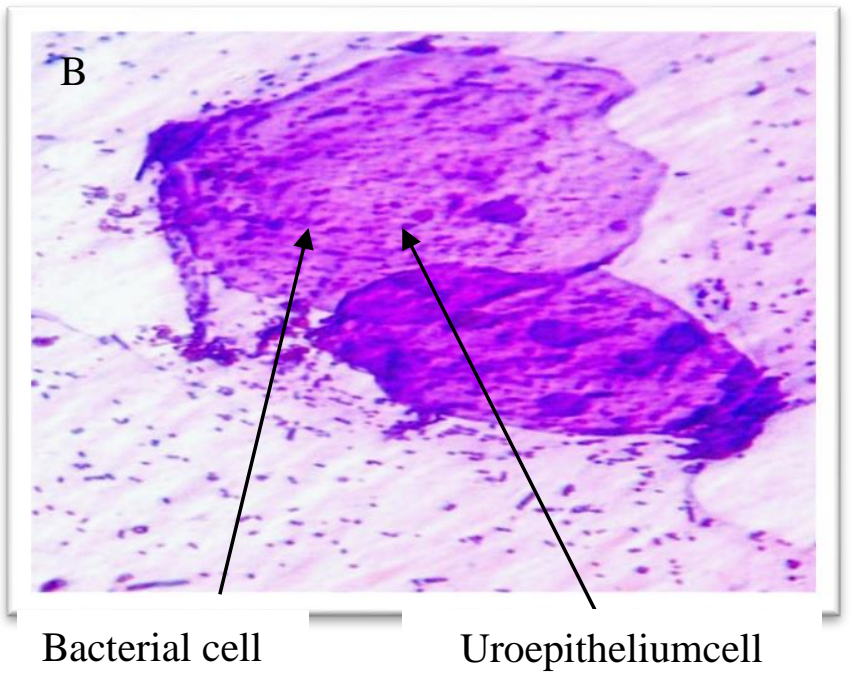

Fig. (') Adherence of Proteus mirabiliscellsto uroepithelium ( $1 \cdots X$ ).

(A) Normal uroepithelium cell.

(B) Uroepithelium cell after adherence of Proteus mirabilis.

Table (')

Adhesion ability of $P$. mirabilis touroepithelial cells.

\begin{tabular}{|c|c|}
\hline Isolate & Adhesion (bacterial cell/uroepithelial cell) \\
\hline P. mirabilis $\mathbf{P}^{\prime}$ & $r \cdot$ \\
\hline P. mirabilis $\mathbf{P Y}$ & rr \\
\hline P. mirabilis $\mathbf{P}^{\mu}$ & rr \\
\hline P. mirabilis $\mathbf{P}\{$ & ro \\
\hline P. mirabilis Po & r. \\
\hline P. mirabilis $\mathbf{P}\urcorner$ & ro \\
\hline P. mirabilis $\mathbf{P V}$ & rr \\
\hline P. mirabilis $\mathbf{P}^{\wedge}$ & $\mathrm{r \Lambda}$ \\
\hline P. mirabilis $\mathbf{P}^{q}$ & $\varepsilon r$ \\
\hline P. mirabilis $\mathbf{P}$ ). & rr \\
\hline P. mirabilis $\mathbf{P} \backslash 1$ & $\varepsilon \cdot$ \\
\hline P. mirabilis $\mathbf{P} \backslash Y$ & $\leqslant 0$ \\
\hline
\end{tabular}




\begin{tabular}{|c|c|}
\hline P. mirabilis $\mathbf{P} \backslash \mathrm{r}$ & ro \\
\hline$P$. mirabilis $\mathbf{P} \backslash\{$ & $r \wedge$ \\
\hline P. mirabilis $\mathbf{P}^{\circ}{ }^{\circ}$ & 00 \\
\hline
\end{tabular}

The difference in adhesion capabilities to uroepithelial cells may be related to the virulence variation between bacterial strains. Gram-negative uropathogensproduce an assortment of adhesins including those attached to the tip of hair-like projections, known as fimbriae or pili, as well as adhesins anchored directly within bacterial cell membranes, known as nonfimbrial adhesions (10).

A gentamicin resistances assay was used as a measure to determine the host invasion mediated by the local isolates of $P$. mirabilis. Results indicated in Table ( $\varepsilon$ ) show the number of bacterial cells not susceptible to gentamicin and gain entry to the uroepithelial cell was ranged between 1 and $r$. bacterial cell/ uroepithelial cell. These results revealed that different isolates of $P$. mirabilis exhibits high invasion ability to epithelial cell and survive intracellular. These results were in agreement with those mentioned by Jacobsen et al. (17) who found that the invasion, cytotoxicity and biofilmformation of $P$. mirabilis and Escherichia colihave been observed in vitro and in vivo to be internalized by bladder and renal epithelial cells. Adhesinmediated invasion of uroepithelial cells is dependent upon the presence of the decay accelerating factor receptor on host cells and may contribute to persistence within the upper urinary tract.

\section{Table ( $\varepsilon)$}

Ability of P. mirabilislocalisolate to invade uroepithelial cells.

\begin{tabular}{|c|c|}
\hline Isolate & $\begin{array}{c}\text { Invasion (bacterial cell/ } \\
\text { uroepithelialcell) }\end{array}$ \\
\hline P. mirabilis $\mathbf{P})$ & - \\
\hline P. mirabilis $\mathbf{P Y}$ & 1 \\
\hline P. mirabilis $\mathbf{P}^{r}$ & $1 \varepsilon$ \\
\hline P. mirabilis $\mathrm{P}^{\varepsilon}$ & $\bar{r}$ \\
\hline P. mirabilis $\mathbf{P}^{\bullet}$ & - \\
\hline P. mirabilis $\mathrm{P}^{\dagger}$ & $\overline{0}$ \\
\hline P. mirabilis $\mathbf{P}^{\vee}$ & - \\
\hline P. mirabilis $\mathbf{P}^{\wedge}$ & $\varepsilon$ \\
\hline
\end{tabular}

\begin{tabular}{|c|c|}
\hline P. mirabilis $\mathbf{P}^{q}$ & 17 \\
\hline P. mirabilis $\mathbf{P} \backslash$. & 11 \\
\hline P. mirabilis $\mathbf{P} \backslash 1$ & Ir \\
\hline P. mirabilis $\mathbf{P} \backslash$ Y & 17 \\
\hline P. mirabilis $\mathbf{P} \backslash \mathrm{r}$ & $\Lambda$ \\
\hline P. mirabilis $\mathbf{P} \backslash \leq$ & - \\
\hline P. mirabilis $\mathbf{P} \backslash 0$ & $r$. \\
\hline
\end{tabular}

Ability of $P$. mirabilis isolates for protease production

Two methods for screening the ability of the localisolates of $P$. mirabilis for protease production as another factor for virulence and pathogenicity:

\section{a. Semi- quantitative screening}

Semi-quantitative screenings for protease production by the local isolates of $P$. mirabilis was achieved by detection the formation of zone of hydrolysis around each colony when grown on skim milk agar medium. Results mentioned in Fig. $(r)$ and Table $\left({ }^{0}\right)$ show that these isolates were able to hydrolyze skim milk agar medium around each colony and forming halo of hydrolysis with variable degrees.

Results mentioned in Table ( $\left.{ }^{\circ}\right)$ also show that the diameter of zone of hydrolysis was ranged between $\left.0_{-}\right) \leq \mathrm{mm}$ for different isolates, among them the isolates $P$. mirabilis $\mathrm{P} / 0$ (isolated from urine) was the most efficient in protease production because it gives the highest diameter of hydrolysis ( $\leqslant \mathrm{mm}$ ) on skim milk agar. It was well known that protease is a proteolytic enzyme responsible for hydrolyzing proteins by attacking peptide bounds in the basic structure of proteins, hence protease produced by bacterial isolates attack casein (the constituent of skim milk protein) in the culture medium and forming a halo of hydrolysis around each colony ( $\mathrm{V}$ ). 


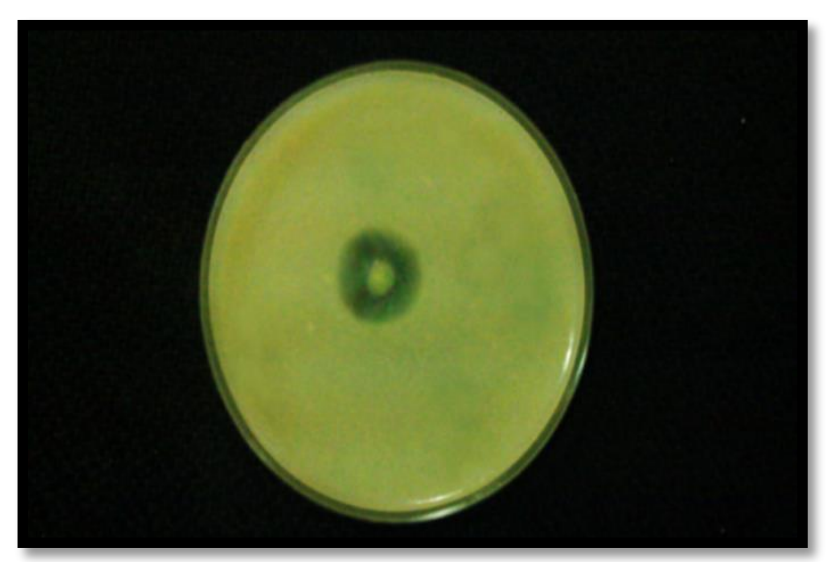

Fig.( ') Protolytic activity of protease produced by $P$. mirabilis on skim milk agar after incubation at ${ }^{m}{ }^{\circ} \mathrm{C}$ for $r \leq h$.

Table ( $\left.{ }^{\circ}\right)$

Diameter of clear zones around colonies of $P$. mirabilis local isolates grown on skim milk agar medium after incubation for $r \leq$ hrs at ${ }^{\mathrm{o}}{ }^{\circ} \mathrm{C}$.

\begin{tabular}{|c|c|}
\hline Isolate & Diameter $(\mathrm{mm})$ \\
\hline P. mirabilis $\mathbf{P} \mid$ & 0 \\
\hline P. mirabilis $\mathrm{Pr}$ & 7 \\
\hline P. mirabilis $\mathbf{P}^{\Gamma}$ & 0 \\
\hline P. mirabilis $\mathbf{P} \leq$ & 7 \\
\hline P. mirabilis Po & $\mathrm{V}$ \\
\hline P. mirabilis $\mathrm{P}^{\top}$ & 7 \\
\hline P. mirabilis $\mathbf{P}^{\vee}$ & 0 \\
\hline P. mirabilis $\mathbf{P}^{\wedge}$ & 0 \\
\hline P. mirabilis $\mathbf{P}^{q}$ & 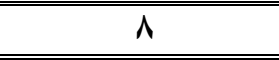 \\
\hline P. mirabilis $\mathbf{P} \backslash$. & $\mathrm{V}$ \\
\hline P. mirabilis $\mathbf{P} \backslash \mid$ & $\mathrm{V}$ \\
\hline P. mirabilis $P \backslash Y$ & $\Lambda$ \\
\hline P. mirabilis $\mathbf{P} \mid \mathrm{Y}$ & 0 \\
\hline P. mirabilis $\mathbf{P} \backslash \leq$ & $\mathrm{V}$ \\
\hline P. mirabilis $\mathbf{P} \backslash 0$ & 15 \\
\hline
\end{tabular}

b. Quantitative screening for protease production by local isolates of $P$. mirabilis Local isolates of $P$. mirabilis were screened quantitatively to examine their ability in protease production. This was achieved by Manachini et al. ( $\wedge)$. Results indicated in Table ( 7 ) showed that all the isolates were protease producers with variable degrees.
Specific activity of protease in culture filtrates was ranged between,,$|r|$ and $1 \leqslant, 0 \mathrm{U} / \mathrm{mg}$ protein. Among them, $P$. mirabilis $\mathrm{P} 10$ was the most efficient in protease production because the specific activity of protease in crude filtrate of this isolate was $1 \leqslant, 0 \mathrm{U} / \mathrm{mg}$ protein. The differences in the ability of the isolates to produce protease are due to genetic variations of the genes responsible for the production of protease $(\backslash \wedge)$.

\section{Table (}

Specific activity of protease produced byP. mirabilis isolates.

\begin{tabular}{|c|c|}
\hline Isolate & Specific activity $(\mathrm{U} / \mathrm{mg})$ \\
\hline P. mirabilis $\mathbf{P} \mid$ & $\cdot,|Y|$ \\
\hline P. mirabilis $\mathbf{P r}^{Y}$ & $r, 11$ \\
\hline P. mirabilis $\mathbf{P}^{\Gamma}$ & $0, \cdot r$ \\
\hline P. mirabilis $\mathrm{P}\{$ & $1, r Y$ \\
\hline P. mirabilis $\mathbf{P}^{\bullet}$ & $r, \cdot V$ \\
\hline P. mirabilis $\mathbf{P}^{\mathbf{r}}$ & $\overline{r, \wedge \uparrow}$ \\
\hline P. mirabilis $\mathbf{P}^{\vee}$ & $Y, \cdot \varepsilon$ \\
\hline P. mirabilis $\mathbf{P}^{\wedge}$ & 1,97 \\
\hline P. mirabilis $\mathbf{P}^{q}$ & $7, \cdot \varepsilon$ \\
\hline P. mirabilis $\mathbf{P}$ ।. & $I Y, \cdot r$ \\
\hline P. mirabilis $\mathbf{P} \backslash 1$ & $\vee, \wedge 9$ \\
\hline P. mirabilis $\mathrm{P} \backslash \mathrm{Y}$ & $\varepsilon, 00$ \\
\hline P. mirabilis $\mathrm{P} \backslash \mathrm{Y}$ & $0, \cdot r$ \\
\hline P. mirabilis $\mathrm{P} \backslash \leq$ & $r, r_{.}$ \\
\hline P. mirabilis $\mathrm{P} 10$ & $1 \leq, 0$. \\
\hline
\end{tabular}

\section{Conclusions}

From these results, it could be concluded that $P$. mirabilis was associated with urinary tract infection and were contaminants of meat and chicken, On the other hand, these local isolates of $P$. mirabilis are able to produce different virulence factors such as invasion and adhesion production and protease production with variable degrees.

\section{References}


Science

['] Giammanco, G. M.; Grimont, P. A.; Grimont, F.; Lefevre, M.; Giammanco, G. and Pignato, S. "Phylogenic analysis of the genera Proteus, Morganella, Providenciab comparison of rpoBgene sequence of type and clinical strains suggestsreclassification of Proteus myxofaciensin a newgenus, Cosenzaeagen. nov., as Cosenzaeamyxofacienscomb. nov"; Int. J. Syst. Evol. Microbiol. $71,17 r \wedge-17 \leqslant \leqslant$, $r+11$.

[ץ] Nielubowicz, G. and Mobley, H.L.T. "Hostpathogeninteractions in urinary tract infections"; Nature Rev. Urology. $v$, $\leqslant r \cdot-$ « $\left.1, r_{\cdot}\right) \cdot$

[ץ] Morgenstein, R. M.; Szostek, B.; Rather, P.N. "Regulation of gene expression during swarmer celldifferentiation in Proteus mirabilis"; FEMSMicrobiol. Rev. rะ, vor_ VTr, r. $\cdot$.

[₹] Isenberg, H. D. "Clinical Microbiological Procedures"; Handbook, rnd edition. Churchill Livingstone, London and New York. pp rч ו_r ro, r...

[0] Atlas, M.; Parks, C. and Brown, A. "Laboratory Manual of Experimental Microbiology" Mosby - Year - Book, Inc., USA. 1990.

[`] Overman, T. L.; Kessler,J. F.; Seabolt, J.P. "Comparison of api r • E ., Api rapid E., and Api rapid NFT to identification of members ofthe family Vibrionaceae"; J.Clin. Microbiol. YY, $V \vee \wedge-V \wedge 1,1910$.

[₹] Iwahi, T., Abc, Y. and Tsuchiya, K. "Virulence of E. coli in a sending urinary tract infection in mice"; J. Med. Microbiol. $10, r \cdot r_{-} T_{17}, 19 \lambda r$.

[^] Sneath, P.H.A.; Mair, N.S.; Sharp, M.E. and Holt, J.G. "Bergeys manual of systematic bacteriology"; pp. $11 \cdot \varepsilon_{-} / 1 \% \wedge$, Williams andwilkins, U.S.A. $19 \wedge$ 7.

[9] Manachini, P.L.; Fortina, M.G. and Parini, C. Appl. "Microbiol. Biotechnol", Ү^:乏॰?, 1919.

[1·]Bradford, M. A. "rapid and sensitive method for the quantitation of microgram quantities of protein using the principle of protein-dye binding"; Anal. Biochem. VY, Y $\leq \Lambda_{-} Y O \leq$. 19VT.

[' '] Stankawska, D.; kwinkowski, M. and Kaka, W. "Quantification Proteus mirabilis virulence factors and modulation by acylatedhomoserine lactones"; J. Microbiol.

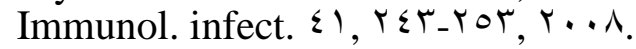

[1Y]Zunino, P.; Sosa, V.; Schlapp, G.; Allen, A.G.; Preston, A.; Sosa, V.; and Maskell, D.J. "Mannose-resistance Proteus- like and
Proteus mirabilis fimbriae have specific and additive roles in P.mirabilisurinary tract infection"; FEMS. Immunol. Med. Microbiol. 01, ir $0_{-} \mid r r, r . . V$.

[1T] Perez-Serrano, J.; Denegri, G.; Casado, N. and Fodriguez-Cabaeiro "In vivoeffect of oral albendazole and albendazolesulphoxide on development ofsecondary echinococcosij in mice"; International Journal for Parasitology. $r v, 1 r \leqslant 1,1 r \leqslant 0$, $199 \mathrm{~V}$.

[1 $]$ Al-Kabby, A. S.A. "Extraction and partial purification for fimbriae from Proteus mirabilis and study their role in adhesion to uroepithlial cells"; M.sc. Thesis/ College of science/ Baghdad University, $Y \cdots V$.

[10] Zunino, P.; Sosa, V.; Schlapp, G.; Allen, A.G.; Preston, A.; Sosa, V.; and Maskell, D.J. "Mannose-resistance Proteus- like and Proteus mirabilis fimbriaehave specific and additive roles in P.mirabilisurinary tract infection"; FEMS. Immunol. Med.

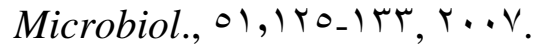

[17] Jacobsen, S. M.; Stickler D. J.; Mobley, H.L.T. and Shirtliff, M. E. "Complicated catheterassociated urinary tract infections due to Escherichia coli and Proteus mirabilis";Clin. Microbiol. Rev. Y ', rч_०१, r...

[I V] Esakkiraj, P.; Immanuel, G.; Sowmya, S. M.; Iyapparaj, P. and Palavesam, A. "Evaluation of protease production ability of fish gut isolates Bacillus cereus for aqua feed"; Food and Bioprocess Technology ${ }^{r}$, rлr_rq., r...

['^] Viji, V. T.; Babu, M. M.; Velmurugan S.; Kumaran, T.; Anand, S.B.; Gunasekaranm, P. and Citarasu, T. "Virulence Factors and Molecular cloning of Outer Membrane Protein (OMP) gene from virulent Aeromonashyrophilaisolated from infected gold fish Carassiusauratus"; Bangladesh J. Microbiol. $r \wedge, \vee \cdot-\vee \vee, r \cdot \mid l$.

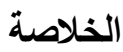

جمعت 10 عينة سريرية وغذائية من مناطق مختلفة من

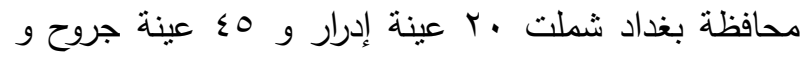
r.

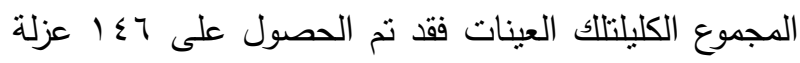
P. Mirabilis بكتيرية، شخصت 10 عزلة منها على انهات وفقا لخصائصها المظهرية والمزرعية و صفاتها الكيموحيوية. وقد تم تأكيد تشخيصها باستخدام العدة التشخيصية -Api. 


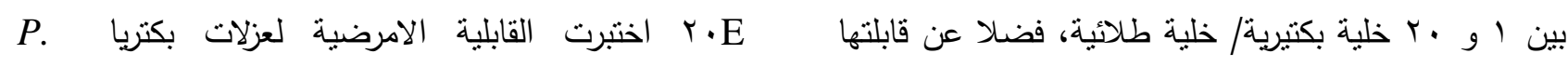

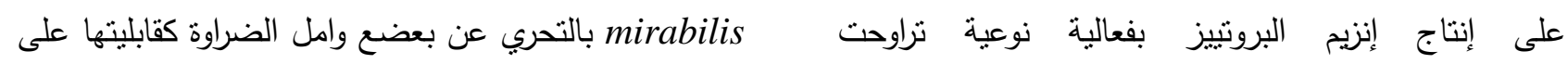

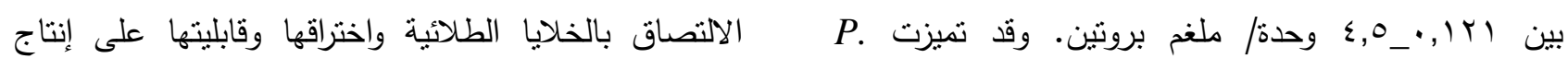

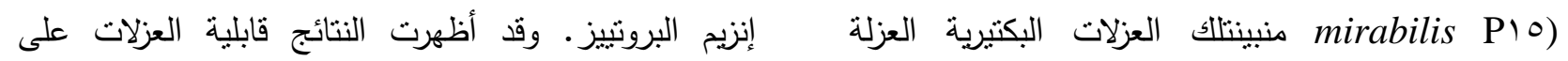

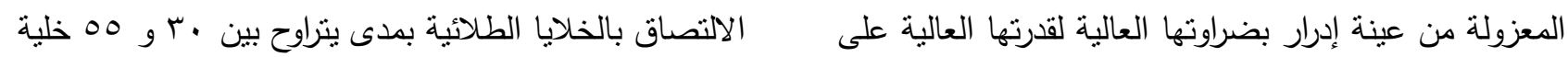

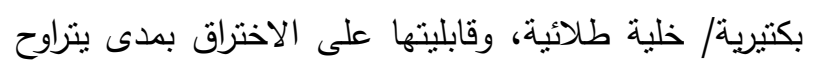
إنتاج عوامل الضراوة. 